\title{
UJI PROFISIENSI ANTAR LABORATORIUM UJI TARIK BAJA TULANGAN SIRIP
}

\section{PROFICIENCY TESTING OF TENSION TESTING OF DEFORMED CARBON-STEEL BARS FOR CONCRETE REINFORCEMENT}

\author{
H. Agus Suhartono, Eka Febriyanti \\ Balai Besar Teknologi Kekuatan Struktur (B2TKS) - BPP. Teknologi \\ PUSPIPTEK Serpong 15314, Telp. 021-7560562 ext. 1069 \\ E-mail : hagussuhartono@yahoo.co.id
}

\begin{abstract}
Abstrak
Pengukuran sifat mekanik yang akurat merupakan suatu hal yang sangat diperlukan dalam perhitungan kekuatan desain suatu struktur. Uji profisiensi antar laboratorium menjamin keamanan dan kehandalan hasil uji. Laboratorium wajib memverifikasi prosedur pengujian dan kapasitasnya untuk mendapatkan hasil uji yang dapat diandalkan. Dalam penelitian ini, benda uji adalah baja tulangan sirip dengan dimensi yang berbeda. Benda uji yang dipilih secara acak memiliki dimensi tertentu dikirim ke masing-masing laboratorium peserta, kemudian diuji dan hasilnya dianalisis sesuai dengan parameter yang ditetapkan sebelumnya. Setiap laboratorium diterapkan tes tarik pada benda uji sesuai dengan prosedur yang diberikan dalam SNI 2052-2002 dan standar uji tarik yang biasa dipergunakan masing-masing laboratorium. Hasil uji dievaluasi sesuai dengan prosedur yang dijelaskan dalam standar terkait. Hasil yang dikumpulkan dievaluasi sesuai dengan metode statistik Robust kemudian Z-score dari laboratorium peserta disajikan. Batas keberterimaan outlier ditetapkan apabila Z-score $>3$. Hasil uji kuat tarik dan kuat luluh dari salah satu laboratorium merupakan outlier pada perhitungan Z-score antar laboratorium. Untuk parameter elongasi terdapat dua laboratorium yang diperingatkan dengan nilai Z-score diantara 2 dan 3.
\end{abstract}

Kata kunci: baja tulangan beton, uji profisiensi, uji tarik

\section{Abstract}

The most crucial characteristic of design of the structure is mechanical strength, so that the measurement accuracy is very essential. Interlaboratory proficiency testing ensures security and reliability of test results. Laboratory testing is required to verify the test procedures and capacity in order to get reliable result. Deform reinforcing steel bar with various dimensions are taken as specimens in this study. The selected test objects were sent randomly to each participant laboratory, then were tested and analyzed according to the parameters previously defined. The tensile tests applied to laboratory test specimens according to the procedures given in SNI 2052-2002 standard and commonly standard used laboratories. The test results are evaluated according to the procedures described. The results collected are evaluated in accordance to statistics. Z-Score from the participants' laboratory are presented. Outlier acceptance limit is set if Z-score> 3. The test result of tensile strength and yield stress from one of the laboratories is an outlier on the $Z$-score calculation between the laboratorium. For elongation parameter, there are two laboratories that are alerted with their Z-score between 2 and 3.

Keywords: reinforced steel bar, proficiency testing, tensile testing

Diterima (received ) : 17 Maret 2017 , Direvisi (revised) : 31 Oktober 2018

Disetujui (accepted) : 06 November 2018 


\section{PENDAHULUAN}

Karakteristik paling mendasar untuk desain struktur mekanik adalah kekuatan tarik. Perkembangan teknologi mengarah pada konstruksi yang ringan tetapi dapat diandalkan, 1,2,3) sehingga keakuratan pengukuran merupakan suatu hal yang sangat diperlukan.

Laboratorium uji mekanik wajib memberi jaminan bahwa pengujian yang dilakukan memberikan data yang akurat, presisi dan konsisten. Perbandingan hasil uji dengan banyak data menurut metode pengujian yang berbeda sangat penting dalam validasi keakuratan dan kebenaran data, seperti dilakukan pada pengukuran sifat mekanik dengan banyak pengulangan dan metode. ${ }^{3,4)}$ Program uji profisiensi (uji banding) dilakukan untuk menjamin hal tersebut. Obyek benda uji adalah baja tulangan sirip yang merupakan bahan konstruksi yang paling banyak diuji di laboratorium mekanik.

Pengelolaan program uji profisiensi dilakukan mengikuti prosedur $4,5,6.7,8)$ yang meliputi dengan persiapan contoh yang mencakup pembuatan contoh, mengevaluasi hasil uji homogenitas, pengiriman contoh ke peserta, pengumpukan hasil dan evaluasi hasil perhitungan statistik. Sebanyak 9 (sembilan) laboratorium peserta berpartisipasi dalam program uji profisiensi dan seluruh laboratorium telah memberikan hasil uji dari laboratoriumnya.

Profisiensi ini dilakukan untuk pemantauan dan evaluasi kinerja serta identifikasi permasalahan di laboratorium guna peningkatan mutu pengujian dalam melakukan pengujian baja tulangan sirip khususnya untuk parameter pengujian yang ditetapkan.

\section{BAHAN DAN METODE}

Bahan baku yang dilakukan pengujian adalah baja tulangan sirip berdiameter 16 $\mathrm{mm}$. Parameter yang akan dilakukan perbandingan adalah regangan/ elongasi $(\%)$, kuat tarik (MPa), dan batas mulur (MPa).

Sesuai prosedur $6,7,9,10)$, uji homogenitas dilakukan sebelum contoh didistribusikan ke laboratorium peserta profisiensi. Pengujian homogenitas dilakukan dengan melaksanakan pengujian pendahuluan terhadap 15 benda uji yang merupakan satu kelompok (heat) yang sama dengan benda uji yang akan dikirimkan ke masing-masing peserta profisiensi. Pengolahan data dan evaluasi dilakukan dan setelah dinyatakan homogen, contoh siap untuk didistribusikan. Setiap peserta diberikan 4 (empat) batang uji baja tulangan sirip yang terdiri dari: 2 (dua) batang uji yang diberi kode B1 dan B2. Laboratorium peserta diminta untuk melakukan pengujian terhadap masingmasing batang contoh uji.

Pengolahan data hasil pengujian yang disampaikan oleh laboratorium peserta dilakukan berdasarkan teknik statistik robust nilai Z (Z-Score). Z-score adalah penyimpangan jumlah standar deviasi dari rata-rata titik data atau ukuran berapa banyak standar deviasi di bawah atau di atas rata-rata populasi. Z-score juga dikenal sebagai skor standar dan dapat diaplikasikan pada sampel yang memiliki kurva distribusi normal.

Mula-mula data hasil pengujian yang dilaporkan, diuji keseragamannya melalui pembuatan histogram. Bila data-data mengikuti distribusi normal maka data dapat langsung diproses dengan menggunakan nilai Z. Bila sebaran data normal namun terdapat beberapa data yang menyimpang secara ekstrim, maka data tersebut harus diseleksi dahulu dengan menggunakan uji Grubbs, kemudian data yang terseleksi diolah dengan menggunakan nilai Z; dan apabila data yang dilaporkan tidak mengikuti sebaran normal (sangat beragam) maka data tidak diolah. Metoda perhitungan statistik robust digunakan untuk mengolah data yang menghasilkan nilai $Z$, dan perhitungan statistik menggunakan rumus sesuai dengan Pedoman Perhitungan Statistik Untuk Uji Profisiensi KAN 4).

Nilai Z dihitung berdasarkan rumus dengan metode berikut. Setelah dilakukan uji keseragaman data, data hasil uji laboratorium tiap karakteristik sampel diurut dari kecil ke besar, kemudian ditentukan Median, Kuartil Atas (Q1), Kuartil Bawah (Q3).

Inter Quartile Range ( IQR ) = Q3 - Q1

dan

Range $=$ nilai maksimum - nilai minimum

Dari hasil perhitungan di atas dilakukan perhitungan nilai $Z$ dengan tahapan sebagai berikut :

- Menentukan nilai Ji:

$\mathrm{Ji}=(\mathrm{Ci}+\mathrm{Di}) / \sqrt{2}$

- Menentukan nilai Bi:

$\mathrm{Bi}=(\mathrm{Ci}-\mathrm{Di}) / \sqrt{2}$,

Jika median $(\mathrm{Ci})>$ median $(\mathrm{Di})$ 
atau

$\mathrm{Bi}=(\mathrm{Di}-\mathrm{Ci})$,

Jika median (Ci) < median (Di)

Data hasil $\mathrm{Ji}$ diurutkan untuk menentukan median Ji:

Nilai Z di antara laboratorium :

$Z_{a i}=\frac{J_{i}-\operatorname{Median}\left(J_{i}\right)}{\operatorname{IQR}\left(J_{i}\right) \times 0,7413}$

Urut data hasil Di menentukan median $\mathrm{Bi}$ :

Nilai $Z$ di dalam laboratorium:

$Z_{d i}=\frac{B_{i}-\operatorname{Median}\left(B_{i}\right)}{\operatorname{IQR}\left(B_{i}\right) \times 0,7413}$

\section{Keterangan:}

$\mathrm{Ji} \quad=$ Jumlah hasil uji sampel 1 dan 2 dibagi akar 2 dari Laboratorium i.

$\mathrm{B}_{\mathrm{i}}$ = Pengurangan hasil uji sampel 1 dan 2 dibagi akar 2 dari Laboratorium i.

$\mathrm{C}_{\mathrm{i}}=$ Hasil uji sampel 1 dari Laboratorium $\mathrm{i}$.

$D_{i}=$ Hasil uji sampel 2 dari Laboratorium i.

Median = Nilai tengah dari sekelompok data $\mathrm{n}$ hitung.

$0.7413=$ Standar distribusi normal.

Nilai Z dari masing-masing laboratorium peserta ditunjukkan pada Grafik nilai Z. Nilai Z-score Laboratorium yang memperoleh kategori outlier dengan robust nilai $Z^{8,9)}$ diminta untuk menyelidiki penyebab dari kesalahan dan melaporkan tindakan perbaikan.

Evaluasi unjuk kerja laboratorium peserta memiliki kategori:

- $|Z s c o r e| \leq 2$ : memuaskan

- $2<\mid Z$ score $\mid<3$ : peringatan

- $|Z s c o r e| \geq 3$ : tidak memuaskan

Dengan mempertimbangkan kategori Zscore dalam uji profisiensi ini, maka batas keberterimaan outlier ditetapkan apabila Zscore $>3$.

Laboratorium peserta diminta untuk melakukan pengujian sesuai dengan metode rutin yang digunakan di laboratorium atau sesuai dengan ruang lingkup akreditasi dengan memperhatikan Petunjuk Bagi Peserta yang dikirimkan bersama-sama contoh uji. Laboratorium diminta mencantumkan kode metode uji yang digunakan.

\section{HASIL DAN PEMBAHASAN}

Hasil pengujian 9 laboratorium peserta dapat dilihat pada tabel 1-3 dan gambar 1-3 berikut.

Tabel 1.

Hasil uji kuat tarik (MPa) pada 9 laboratorium

\begin{tabular}{ccc}
\hline $\begin{array}{c}\text { Kode } \\
\text { Lab }\end{array}$ & \multicolumn{2}{c}{ Batang Uji } \\
\hline BT 01 & 518.89 & B2 \\
BT 02 & 632.0 & 520.16 \\
BT 03 & 626.6 & 619.0 \\
BT 04 & 613.5 & 613.3 \\
BT 05 & 641.6 & 639.1 \\
BT 06 & 634.6 & 637.9 \\
BT 07 & 611.8 & 616.8 \\
BT 08 & 649.3 & 651.7 \\
BT 09 & 620 & 615 \\
\hline
\end{tabular}

Tabel 2.

Hasil uji kuat luluh (MPa) 9 laboratorium uji

\begin{tabular}{ccc}
\hline $\begin{array}{c}\text { Kode } \\
\text { Lab }\end{array}$ & \multicolumn{2}{c}{ Batang Uji } \\
\hline BT 01 & 385.81 & B2 \\
BT 02 & 497.6 & 568.25 \\
BT 03 & 463.6 & 444.0 \\
BT 04 & 489.7 & 492.3 \\
BT 05 & 497.4 & 497.4 \\
BT 06 & 497.2 & 501.0 \\
BT 07 & 424.5 & 424.5 \\
BT 08 & 518.7 & 519.8 \\
BT 09 & 493 & 483 \\
\hline
\end{tabular}

Tabel 3.

Hasil uji elongasi (\%) pada 9 laboratorium

\begin{tabular}{ccc}
\hline $\begin{array}{c}\text { Kode } \\
\text { Lab }\end{array}$ & \multicolumn{2}{c}{ Batang Uji } \\
\hline BT 01 & 22.65 & B2 \\
BT 02 & 20.2 & 10.93 \\
BT 03 & 19.6 & 20.0 \\
BT 04 & 18.2 & 18.2 \\
BT 05 & 24.0 & 23.1 \\
BT 06 & 18.3 & 19.3 \\
BT 07 & 15.6 & 17.2 \\
BT 08 & 20.8 & 20.5 \\
BT 09 & 20.6 & 20.9 \\
\hline Sumber Data: Hasil Olahan Data Penelitian
\end{tabular}



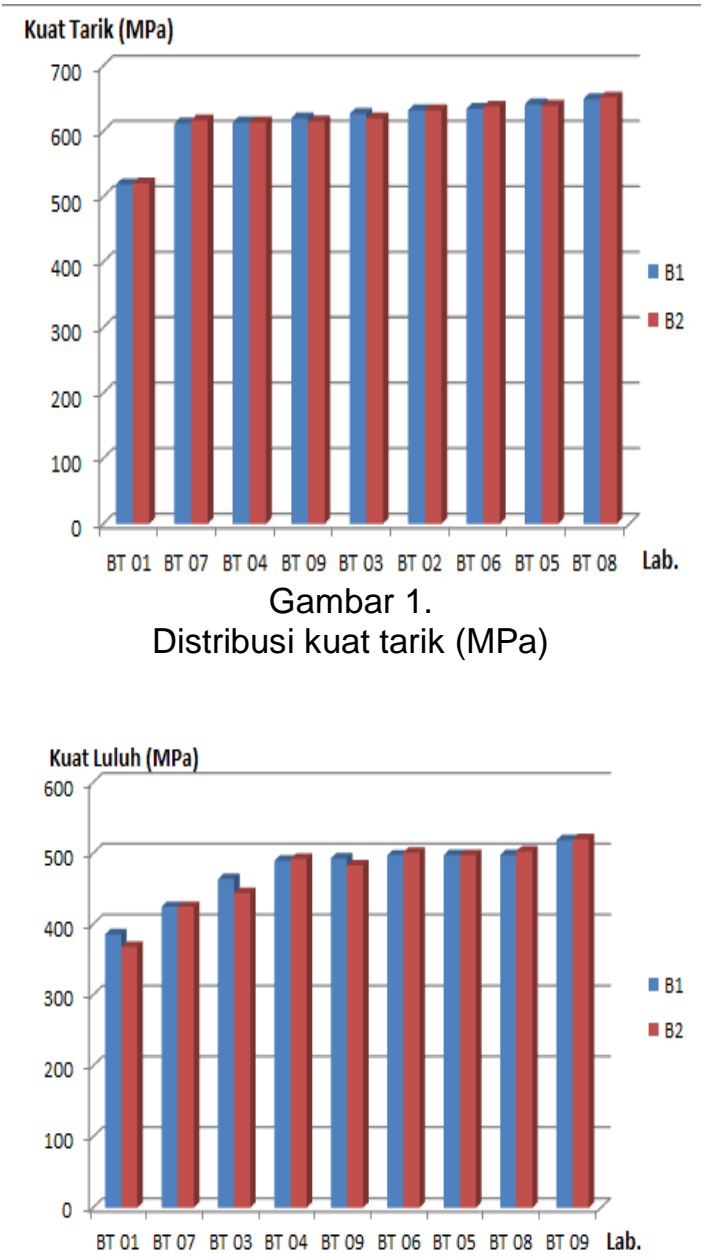

Gambar 2.

Distribusi kuat luluh (MPa)

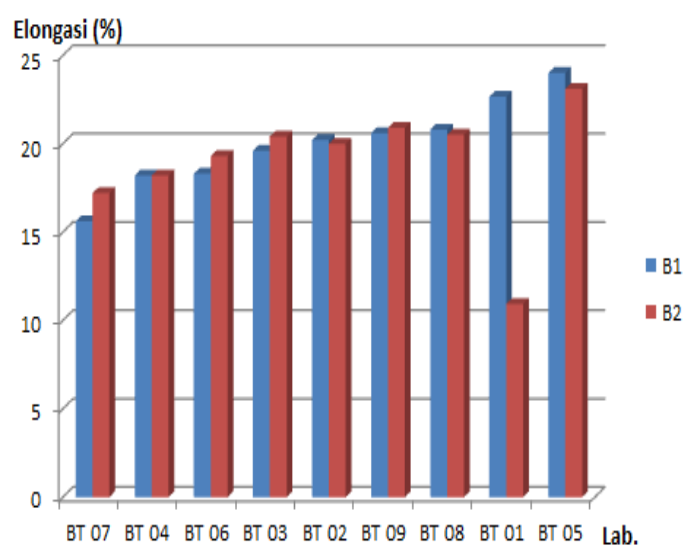

Gambar 3.

Distribusi elongasi (\%)

Parameter batas ulur dan kuat tarik, data elongasi, secara keseluruhan menunjukkan distribusi seperti ditunjukkan pada gambar 1 , gambar 2 dan gambar 3 .
Tabel 4.

Perhitungan Nilai Z, Baja Tulangan sirip, parameter: kuat tarik (MPa)

\begin{tabular}{ccccc}
\hline $\begin{array}{c}\text { Kode } \\
\text { Lab }\end{array}$ & $\begin{array}{c}\text { Kuat Tarik (Mpa) } \\
\text { B1 }\end{array}$ & $\begin{array}{c}\text { B2-score } \\
\text { antar } \\
\text { Lab }\end{array}$ & $\begin{array}{c}\text { Z-score } \\
\text { dalam } \\
\text { Lab }\end{array}$ \\
\hline BT 01 & 518.89 & 520.16 & -6.37 & -0.35 \\
BT 02 & 632.00 & 632.00 & 0.54 & 0.00 \\
BT 03 & 626.60 & 619.70 & 0.00 & 1.90 \\
BT 04 & 613.50 & 613.30 & -0.60 & 0.06 \\
BT 05 & 641.60 & 639.10 & 1.06 & 0.69 \\
BT 06 & 634.60 & 637.90 & 0.81 & -0.91 \\
BT 07 & 611.80 & 616.80 & -0.54 & -1.38 \\
BT 08 & 649.30 & 651.70 & 1.68 & -0.66 \\
BT 09 620.00 & 615.00 & -0.35 & 1.38 \\
Jumlah Lab & 9 & 9 & \\
$\quad$ Median & 626.6 & 619.7 & \\
Norm IQR & 15.64 & 16.98 & \\
Robust CV (\%) & 2.50 & 2.74 & \\
Minimum & 518.89 & 520.16 & \\
Maksimum & 649.3 & 651.7 & \\
Rentang & 130.41 & 131.54 & \\
\hline
\end{tabular}

Tabel 5

Perhitungan Nilai Z, Baja Tulangan sirip, parameter: kuat luluh (MPa)

\begin{tabular}{|c|c|c|c|c|}
\hline \multirow[t]{2}{*}{$\begin{array}{l}\text { Kode } \\
\text { Lab }\end{array}$} & \multicolumn{2}{|c|}{$\begin{array}{l}\text { Kuat Luluh } \\
\text { (Mpa) }\end{array}$} & \multirow{2}{*}{$\begin{array}{c}\text { Z-score } \\
\text { antar } \\
\text { Lab }\end{array}$} & \multirow{2}{*}{$\begin{array}{c}\text { Z-score } \\
\text { dalam } \\
\text { Lab }\end{array}$} \\
\hline & B1 & B2 & & \\
\hline BT 01 & 385.81 & 368.25 & -3.39 & 1.88 \\
\hline BT 02 & 497.60 & 502.60 & 0.27 & -0.54 \\
\hline BT 03 & 463.60 & 444.00 & -1.11 & 2.10 \\
\hline BT 04 & 489.70 & 492.30 & 0.00 & -0.28 \\
\hline BT 05 & 497.40 & 497.40 & 0.19 & 0.00 \\
\hline BT 06 & 497.20 & 501.00 & 0.24 & -0.41 \\
\hline BT 07 & 424.50 & 424.50 & -1.98 & 0.00 \\
\hline BT 08 & 518.70 & 519.80 & 0.84 & -0.12 \\
\hline BT 09 & 493.00 & 483.00 & -0.09 & 1.07 \\
\hline \multicolumn{2}{|c|}{ Jumlah Lab } & 9 & 9 & \\
\hline \multicolumn{2}{|c|}{ Median } & 493 & 492.3 & \\
\hline \multicolumn{2}{|c|}{ Norm IQR } & 25.06 & 42.25 & \\
\hline \multicolumn{2}{|c|}{ Robust CV (\%) } & 5.08 & 8.58 & \\
\hline \multicolumn{2}{|c|}{ Minimum } & 385.81 & 368.25 & \\
\hline \multicolumn{2}{|c|}{ Maksimum } & 518.7 & 519.8 & \\
\hline \multicolumn{2}{|c|}{ Rentang } & 132.89 & 151.55 & \\
\hline
\end{tabular}


Tabel 6.

Perhitungan Nilai Z, Baja Tulangan sirip, parameter: Elongasi (\%)

\begin{tabular}{|c|c|c|c|c|}
\hline \multirow{2}{*}{$\begin{array}{l}\text { Kode } \\
\text { Lab }\end{array}$} & \multicolumn{2}{|c|}{ Kuat Tarik (Mpa) } & \multirow{2}{*}{$\begin{array}{c}\text { Z-score } \\
\text { antar } \\
\text { Lab }\end{array}$} & \multirow{2}{*}{$\begin{array}{c}\text { Z-score } \\
\text { dalam } \\
\text { Lab }\end{array}$} \\
\hline & B1 & B2 & & \\
\hline BT 01 & 22.65 & 10.93 & * & * \\
\hline BT 02 & 20.2 & 20.0 & 0.033 & -0.11 \\
\hline BT 03 & 19.6 & 20.4 & -0.033 & -0.70 \\
\hline BT 04 & 18.2 & 18.2 & -1.2 & 0.65 \\
\hline BT 05 & 24.0 & 23.1 & 2.3 & 0.32 \\
\hline BT 06 & 18.3 & 19.3 & -0.8 & 0.00 \\
\hline BT 07 & 15.6 & 17.2 & -2.4 & 2.64 \\
\hline BT 08 & 20.8 & 20.5 & 0.4 & 1.19 \\
\hline BT 09 & 20.6 & 20.9 & 0.5 & -0.76 \\
\hline \multicolumn{2}{|c|}{ Jumlah Lab } & 8 & 8 & \\
\hline \multicolumn{2}{|c|}{ Median } & 19.900 & 20.2 & \\
\hline \multicolumn{2}{|c|}{ Norm IQR } & 1.8 & 1.2 & \\
\hline \multicolumn{2}{|c|}{ Robust CV (\%) } & 8.8 & 5.8 & \\
\hline \multicolumn{2}{|c|}{ Minimum } & 15.6 & 17.2 & \\
\hline \multicolumn{2}{|c|}{ Maksimum } & 24 & 23.1 & \\
\hline \multicolumn{2}{|c|}{ Kisaran } & 8.4 & 5.9 & \\
\hline \multicolumn{5}{|c|}{$\begin{array}{l}\text { * Tidak diperhitungkan karena outlier pada } \\
\text { evaluasi homogenitas dengan uji Grubb }\end{array}$} \\
\hline
\end{tabular}

Untuk menguji apakah distribusi tersebut memiliki distribusi normal maka dilakukan pengujian kenormalan distribusi dengan metode statistic Lilifors 10,11) yang merupakan perkembangan dari uji Kolmogorov-Smirnoff dengan derajat probabilitas a $5 \%$. Pengujian statistik menunjukkan bahwa distribusi untuk nilai kekuatan tarik dan kekuatan luluh memenuhi syarat sebagai distribusi normal. Sedangkan distribusi hasil uji pengukuran elongasi tidak memenuhi distribusi normal pada hasil uji pada Laboratorium BT 01. Dan data elongasi pada Lab Uji BT 01 tidak diikutkan dalam perhitungan Z-Score karena hasil perhitungan menunjukkan bahwa data tersebut merupakan outlier, jadi untuk elongasi perhitungan Z-Score hanya diwakili oleh 8 Laboratorium.

Data-data selanjutnya diuji dalam pengolahan statistik nilai Z. Hasil pengolahan data di tunjukkan pada Tabel 4, Tabel 5 dan Tabel 6.

Evaluasi data hasil uji profisiensi kuat tarik baja tulangan sirip dilakukan oleh 9 laboratorium di seluruh Indonesia terhadap benda uji baja tulangan yang terdiri atas: baja tulangan sirip standar berdiameter 16 $\mathrm{mm}$ dengan kode B1 dan B2. Dan ditunjukkan pada gambar 4, 5 dan 6 .

Evaluasi nilai $Z$ untuk data uji kuat tarik menunjukkan bahwa dari 9 laboratorium yang mengirimkan data terdapat 1 outlier untuk kategori nilai $Z$ antar laboratorium dan tidak terdapat outlier untuk kategori nilai $\mathbf{Z}$ dalam laboratorium. Untuk parameter kuat Iuluh terdapat 1 outlier yaitu laboratorium BT 01 untuk kategori nilai $Z$ antar laboratorium namun untuk Nilai $Z$ dalam laboratorium tidak terdapat outlier.

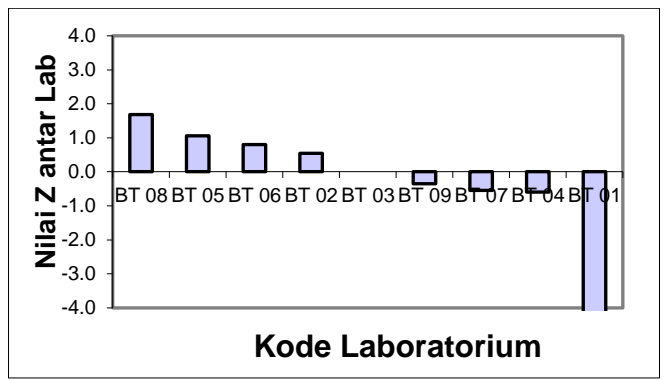

(a)

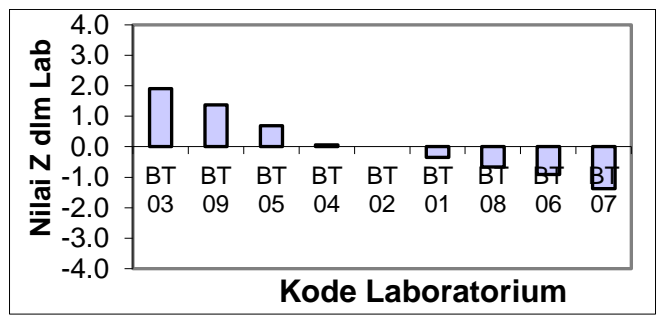

(b)

Gambar 4.

(a) Nilai $Z$ dalam laboratorium

(b) Nilai $Z$ antar laboratorium untuk parameter Kuat Tarik

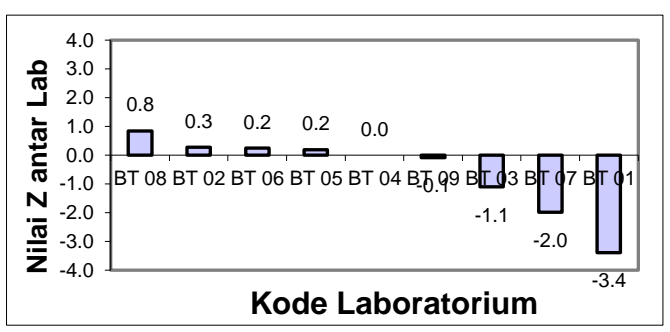

(a)

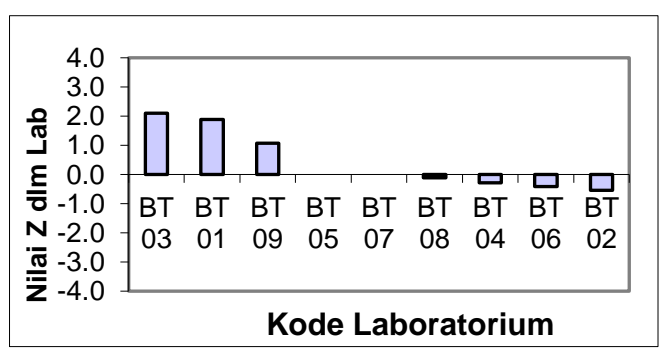

(b)

Gambar 5.

(a) Nilai $Z$ dalam laboratorium

(b) Nilai $Z$ antar laboratorium untuk parameter Kuat Luluh (Mpa) 
Terjadinya outlier baik antar laboratorium maupun dalam laboratorium untuk parameter kuat tarik dapat disebabkan oleh kontribusi dari salah satu atau gabungan dari faktorfaktor yang diberikan berikut ini diantaranya: kesalahan interface antara load cell dan load indicator atau $\mathrm{X}-\mathrm{Y}$ recorder, kesalahan penunjukan instrumen, atau kalibrasi load cell pada cakupan beban yang digunakan tidak dilakukan.

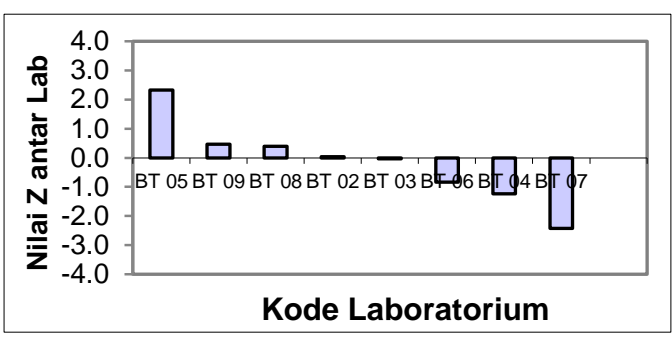

(a)

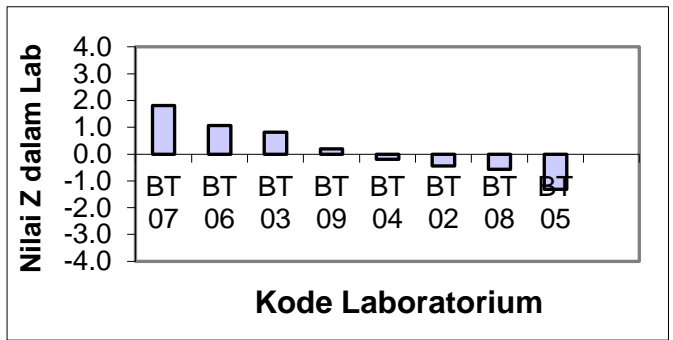

(b)

Gambar 6.

(a) Nilai $Z$ dalam laboratorium dan

(b) Nilai $Z$ antar laboratorium untuk parameter Elongasi

Dari hasil pengiriman data elongasi tampak ada data yang tidak konsisten dengan pengamatan lain dalam kelompok populasi tersebut. Untuk mengetahui apakah data dalam populasi tersebut memenuhi kaidah distribusi normal dilakukan uji dengan metode Grubbs Test. Hasil evaluasi menunjukkan bahwa terdapat satu hasil dari dinyatakan outlier karena nilai Grubbs eksperimen hasil perhitungan melebihi nilai Grubbs kritis yang ditetapkan.

Evaluasi nilai $Z$ dengan parameter elongasi untuk benda uji B1 dan B2, hanya dilakukan terhadap 8 laboratorium saja dari 9 laboratorium yang mengirimkan data hasil uji elongasi. Berdasarkan Nilai Z-score antar laboratorium tidak terdapat outlier dari datadata tersebut, dan ada 2 laboratorium yaitu BT 05 dan BT 07 yang nilai Z-score nya pada diperingatkan. Terdapat 1 laboratorium yang outlier pada saat $d$ untuk kategori Zscore antar laboratorium yaitu laboratorium BT 02 dan BT7. Serta terdapat outllier 1 laboratorium yaitu BT 07 yang outlier untuk kategori nilai Z intra-laboratorium/ dalam laboratorium.

Terjadinya outlier baik antar laboratorium maupun dalam laboratorium untuk parameter elongasi dapat disebabkan oleh kontribusi dari salah satu atau gabungan dari faktorfaktor yang diberikan berikut ini yaitu: benda uji putus di dekat pencekam, kekurangtelitian dalam mengukur panjang benda uji sebelum atau setelah patah, kecepatan pembebanan yang terlalu tinggi.

\section{SIMPULAN}

Dari hasil uji profisiensi dapat disimpulkan bahwa pengolahan data hasil uji profisiensi harus diaplikasikan pada sampel yang memiliki kurva distribusi normal. Hasil profisiensi digunakan untuk mendeteksi laboratorium dan memperbaiki yang pengukuran yang melenceng dari nilai ratarata. Kategori keberterimaan $Z$ score yaitu: $\mid Z$ score $\mid \leq 2$ :memuaskan; $2<\mid Z$ score $\mid<3$ peringatan; $\mid Z$ score $\mid \geq 3$ : tidak memuaskan .Hasil uji kuat tarik dan kuat luluh diketahui bahwa satu Laboratorium merupakan outlier pada perhitungan Z-score antar laboratorium.Satu laboratorium diperingatkan pada perhitungan Z-score dalam laboratorium. Untuk parameter elongasi terdapat satu laboratorium yang diperingatkan dengan nilai Z-score diantara 2 dan 3 pada perhitungan Z-score antar laboratorium dan pada perhitungan Z-score dalam laboratorium. Laboratorium yang mendapat nilai sebagai outlier harus segera memperbaiki prosedur pengujian dan mereview mesin serta instrumen uji secara menyeluruh.

\section{DAFTAR PUSTAKA}

1. Wang, H.T., L.C. Wang, Experimental study on static and dynamic mechanical properties of steel fiber reinforced lightweight aggregate concrete, Construction and Building Materials, Volume 38, (January 2013), p.11461151.

2. Ergul, Y., D.A. Cengiz, K. Alaettin, Strength properties of lightweight concrete made with basaltic pumice and fly ash, Mater Lett, 57 (15) (2003), p. 2267-2270.

3. Haque, M.N., H. Al-Khaiat, O. Kayali, Strength and durability of lightweight concrete, Cem Concr Compos, 26 (4) (2004), pp. 307-314.

4. Motraa, H.B., J. Hildebrandb, A. Dimmig-Osburgc, Assessment of strain measurement techniques to 
characterise mechanical properties of structural steel, Engineering Science and Technology, an International Journal, Volume 17, Issue 4, (December 2014), Pages 260-269.

5. Komite Akreditasi Nasional, Pedoman Perhitungan statistik untuk Uji Profisiensi, Persyaratan Umum Kompetensi Laboratorium Pengujian dan Laboratorium Kalibrasi, ISO/IEC 17025 (Versi Bahasa Indonesia), Juli 2004.

6. Use of Proficiency Testing as a Tool for Accreditation in Testing. Diunduh dari

http://www.ilac.org/documents/ILAC G22 2004 use of proficiency testin g_as_a_tool_for_accreditation_in_tes ting.pdf, diakses tahun 2012

7. Report No. 770, Tensile Testing of Metals Proficiency Testing Program Round 4, Proficiency Testing, Australia 2012.

8. Report No. 823, Tensile Testing of Metals, Proficiency Testing Program Round 5, Proficiency Testing, Australia September 2013.
9. Leys, C., O. Klein, P. Bernard, L. Licata, Detecting outliers: Do not use standard deviation around the mean, use absolute deviation around the median, Journal of Experimental Social Psychology Volume 49, Issue 4, (July 2013), p.764-766.

10. Yuen, K., H.Q. Mu, Probabilistic Engineering Mechanics, $A$ novel probabilistic method for robust parametric identification and outlier detection, Volume 30, (October 2012), p.48-59.

11. Normality Tests for Statistical Analysis: A Guide for NonStatisticians, International Journal of Endocrinology and Metabolism, Volume 10(2), (April 2012), p.486489.

12. Noiman, S.A., L.D. Brown, A. Buja, W. Rolke \& R.A. Stine, The Power to See: A New Graphical Test of Normality, Journal The American Statistician, Volume 67, 2013. 
(halaman ini sengaja dikosongkan) 